\title{
SOME BIOCHEMICAL CHANGES IN PATIENTS WITH ACUTE ISCHEMIC STROKE
}

\author{
O. Ja. MYKHALOJKO, I. Ja. MYKHALOJKO
}

Ivano-Frankivsk National Medical University, Ukraine;

e-mail:myhalojko@i.ua

The aim was to determine the alterations in levels of vasculair endothelial growth factor (VEGF), homocysteine (HC) and lipid profile in patients with acute ischemic stroke (AIS), to establish the relationship between them. A clinical and neurological examination of 120 patients aged 56 to 75 years with AIS was done. Diagnosis was established taking into account results of spiral computer and magnetic resonance tomography. The control group included 20 people with no signs of acute cerebrovascular and severe somatic pathology aged $59.35 \pm 1.8$ years. Assessment of disability was performed at admission and during the treatment using the scale NIHSS. In all relevant patients in 1-2 days after stroke, the concentration of HC and VEGF levels was determined by ELISA. Blood lipid profile was determined by enzymatic colorimetric method. The study found that increasing concentration of plasma HC is associated with intensity of hyperlipidemia, and hyperhomocysteinemia severity prevails over the changes in the lipid profile components. During AIS a significant increase in the level of VEGF in the blood was observed, indicating the presence of vascular accident and activation of angiogenesis. Severity of vascular endothelial lesions is associated with the degree of increasing concentration VEGF that appears most significant in patients with severe AIS.

Key words: acute ischemic stroke, vasculair endothelial growth factor (VEGF), homocysteine, blood lipid profile.

A nnually in Ukraine 100-120 thousand of strokes are registered, and more than $30 \%$ - in people of working age. About $50 \%$ of patients die within the first year after a stroke, a third of those who survived, is severely disabled.

These statistics motivate scientists to more detailed study biochemical cascade of brain damage in order to identify new trends and strategies in the diagnosis and treatment of ischemic stroke.

The results of one of the largest study MONICA, which covered 21 countries, found that known risk factors (smoking, hypertension, overweight and atherosclerosis) can not fully explain the occurrence of cardiovascular and cerebrovascular diseases, since their prevalence reaches 15\% in women and $40 \%$ in men [1-4]. In this regard, the search for new risk factors is necessary, identification of which would affect the level of mortality from cerebrovascular disease [5, 6]. Among the potential causes of vascular brain accidents, which are of great interest in experts, a special place belongs to hyperhomocysteinemia (HHC). Homocysteine (HC) - a sulfur natural aminoacid that is not found in proteins, and is the product of the degradation of methionine - one of the 8 essential aminoacids in the body $[7,8]$. Among the factors affecting the level of $\mathrm{HC}$ and increase the likelihood of its content in the blood include vitamine deficiency, smoking, alcohol abuse, diet with high content of meat food and food with high cholesterol level. We know also that the $\mathrm{HHC}$ can be hereditary disease caused by deficiency of enzymes involved in the metabolism of $\mathrm{HC}$ [3, $5,9,10]$. In the case of HC excess in the body it accumulates in the blood, and the main place of the harmful effects of this substance is the inner surface of blood vessels. There are evidence that HHC causes damage and activation of endothelial cells, which significantly increases the risk of thrombosis, causes “oxidative stress”, increases platelet aggregation. Activation of the coagulation cascade leads to disruption of endothelium dependent vasodilatation

(C) 2017 Mykhalojko O. Ja., Mykhalojko I. Ja. This is an open-access article distributed under the terms of the Creative Commons Attribution License, which permits unrestricted use, distribution, and reproduction in any medium, provided the original author and source are credited. 
and stimulate proliferation of smooth muscle cells. So HHC has a negative effect on the mechanisms regulating vascular tone, lipid metabolism and coagulation cascade, contributing to the development of various vascular diseases $[1,4,6,7]$. Given the significant negative impact of $\mathrm{HC}$ on the vascular wall and insufficient justification of its role in acute ischemic stroke (AIS), the object of our interest was the study of the prevalence HHC in healthy subjects and in patients with AIS and clarify the interaction of HHC with risk factors as hyperlipidemia. The most influential physiological inhibitor of programmed cell death among other are growth factors. They reduce the concentration of apoptotic effectors or their activity to a safe level and stimulate the process of angiogenesis, which is necessary for long-term adaptation of tissues in state of damage [11-13]. The subject of our interest was just vascular endothelial growth factor (VEGF), whose role remains uncertain for the formation of brain damage. Proved that VEGF - is angiogenic protein, which is released in response to hypoxia with marked damage microvasculature and is a major inducer of angiogenesis $[14,15]$. In the blood of healthy individuals free VEGF content is low, it is usually expressed on platelets and appears in a free state in large numbers at their excessive activation or damage, however, increased plasma VEGF may reflect a process of rising activity of compensatory and protective mechanisms (angiogenesis) and increasing the permeability of blood-brain barrier due to hypoxia, reflecting the deepening of pathological changes [12, 14]. Given discrepancy of versions and research results, it is reasonable to study changes in VEGF concentration in acute cerebral ischemia and establish the presence of interrelation HHC and hypercholesterolemia.

The aim - to determine the concentration changes of vascular endothelial growth factor, homocysteine and lipide profile in patients with acute ischemic stroke and to establish the relationship between them.

\section{Materials and Methods}

A clinical - laboratory analysis of 120 patients with AIS aged 56 to 75 years. All patients were admitted in the first 24-48 hours from the onset of clinical manifestations of disease. The diagnosis is verified using spiral computer and magnetic resonance tomography. The control group consisted of 20 people with no signs of acute cerebrovascular accident and severe somatic pathology age (59.35 \pm 1.80$)$ years. Stroke severity was determined according to the scale NIHSS. (National Institutes of Health Stroke Scale, USA). The level of VEGF in the blood was determined using ELISA kits Biosource (USA) on 1-2 day illness. HC serum levels were determined using ELISA kits Axis Homocysteine EL, production Axis-Shield Diagnostics Ltd the Tehnology ParkDundee DD2, XA United Kingdom on 1-2-nd day after the onset of disease. Blood lipid spectrum was determined by using enzymatic colorimetric method for biochemical analyzer Screen master lab production Hospitex diagnostik (Germany) with a certain detrmination of total cholesterol level (TC), triglycerides (TG), high density lipoprotein cholesterol (HDL). The content of low-density lipoprotein cholesterol (LDL) was calculated using the equation W. Freedwald: LDL cholesterol $=$ TC - (HDL cholesterol + TG/2.2); cholesterol lipoprotein very low density $(\mathrm{VLDL})$ : VLDL $=\mathrm{TG} / 2.2$. Atherogenic factor the equation of Klimov A. N : AF = (HDL-C)/HDL.

Statistical analysis of the data was performed using universal statistical software "Excel 5.0" to a personal computer for the definition of the mean value. For authenticity difference between groups was used Student test $(t)$. The difference between groups acknowledged significant at $(P<0.05)$.

\section{Results and Discussion}

$\mathrm{HC}$ level in control group was $8.45 \pm 0.30 \mathrm{mmol} / \mathrm{l}$. In all surveyed patients with AIS on 1-2 day of illness HC content corresponded $17.57 \pm 1.1 \mathrm{mmol} / \mathrm{l}$, respectively which was significantly higher compared to control $(P<0.001)$. In the study, we have observed widely oscillations in severity of HHC and dependence of HC level from the severity of the neurological deficit. (14.1\%) patients with mild stroke level HC was $10.8 \pm 0.12 \mathrm{mmol} / \mathrm{l}(P<0.05)$; in patients with moderate stroke (45.8\%) $15.9 \pm 0.32 \mathrm{mmol} / \mathrm{l}(P<0.001)$. In patients with severe stroke (40\%) had the most high levels HHC and grew more than two time compared the control group and were $19.5 \pm 0.5 \mathrm{mmol} / \mathrm{l}(P<0.001)$. In patients with severe AIS and premorbid background which included hypertension combined with cerebral atherosclerosis and diabetes with a history of multiple thrombotic episodes (transient ischemic attack, ischemic stroke, myocardial infarction) significantly higher values of serum $\mathrm{HC}$ were recorded which reached $25.3 \pm 0.3 \mathrm{mmol} / \mathrm{l}$. It should be noted that patients with AIS in vertebrobasilar pool, which arose as a result external vascu- 
lar compression on the background of degenerative disc disease of the cervical spine, level HC was at the upper limit of normal, indicating lack of impact of HC on destructive changes in cervical spine. In all patients with AIS was found increased level of VEGF $(378.5 \pm 44.6) \mathrm{pg} / \mathrm{ml}(P<0.001)$ compared to $(105.5 \pm 8.74) \mathrm{pg} / \mathrm{ml}$ in the control group, indicating the presence of "vascular accident" and activation of angiogenesis. VEGF, providing growth of new capillaries and arterial collaterals, the recovery of perfusion in the area penumbry, creating a positive effect and can be used as a method of therapy. Severity of vascular endothelial lesions was associated with the degree of expression of VEGF. This pattern is the most often revealing in the examined patients with severe AIS $(453.5 \pm 44.6)(P<0.001)$, in mild cases increase in VEGF concentration in blood was lowest $(190.8 \pm 12.52) \mathrm{pg} / \mathrm{ml},(P<0.05)$. It should be noted that in older patients with severe stroke VEGF concentration was lower compared to younger patients, which probably indicates exhaustion of angiogenesis with age and less activity of reparative processes. In assessing the state of lipid metabolism in 1-2 day illness changes of all parameters of lipide profile were compared with the control group $(P<0.05)$. Levels of HDL, LDL, VLDL cholesterol and triglycerides were increased significantly compared with control $(P<0.05)$ and HDL cholesterol level decreased $(P<0.05)$, which explains the presence of atherosclerotic lesions of cerebral vessels (Table).

Attention is drawn to the fact that in patients with AIS hyperhomocysteinemia growth and VEGF are expressed to a greater extent compared to the severity of their hyperlipidemia. In patients with acute ischemic stroke a direct strong correlation connection between plasma levels of HC content and TC $(r=0.71 ; P<0.01)$, LDL cholesterol $(r=0.72$; $P<0.01)$, and direct medium strength connection between HC and TG $(r=0.31 ; P<0.05)$, VLDL $(r=0.59 ; P<0.01)$ and AF $(r=0.69 ; P<0.01)$. Reliable reverse connection of average force is established between the level of plasma HDL and HC $(r=-0.43 ; P<0.05)$. This confirmed the impact of hyperhomocysteinemia on the activation process of atherogenesis and lowering blood levels of proaterogenic factors (Fig. 1).

Conducting correlation analysis between the lipid spectrum of serum and VEGF in patients with AIS we identified a direct strong correlation between the level of VEGF and content TC ( $r=0.72$; $P<0.01)$, LDL cholesterol $(r=0.71, P<0.01)$, and
Lipid profile in patients with acute ischemic stroke

\begin{tabular}{l|c|c}
\hline $\begin{array}{c}\text { Lipide } \\
\text { profile, } \\
\mathrm{mM} / \mathrm{l}\end{array}$ & $\begin{array}{c}\text { Control group } \\
(M \pm m, n=20)\end{array}$ & $\begin{array}{c}\text { AIS patients } \\
(n=120, P<0.05)\end{array}$ \\
\hline TC & $4.62 \pm 0.11$ & $5.98 \pm 0.21$ \\
HDL & $1.53 \pm 0.06$ & $1.06 \pm 0.08$ \\
LDL & $2.53 \pm 0.14$ & $3.55 \pm 0.33$ \\
VLDL & $0.57 \pm 0.04$ & $0.95 \pm 0.17$ \\
TG & $1.36 \pm 0.15$ & $3.05 \pm 0.15$ \\
\hline
\end{tabular}

a direct medium strength relationship between VEGF and TG $(r=0.50 ; P<0.05)$, VLDL $(r=0.52$; $P<0.05)$ and AF $(r=0.47 ; P<0.05)$. Also we found reverse medium strength connection between the level of VEGF and HDL $(r=-0.45 ; P<0.05)$ (Fig. 2).

The presence of interrelation between VEGF and blood lipid spectrum in patients with AIS confirms the hypothesis of activation of protective mechanisms such as angiogenesis process in the atherosclerotic blood vessels, which contributes to the restoration of collaterals and perfusion in the area penumbry. After analysis of the correlation between the concentration of VEGF and plasma HC was found direct strong correlation $(r=0.79$; $P<0.001)$. Thus, the process autooxidation of HC in plasma occurs with the formation of free radicals,

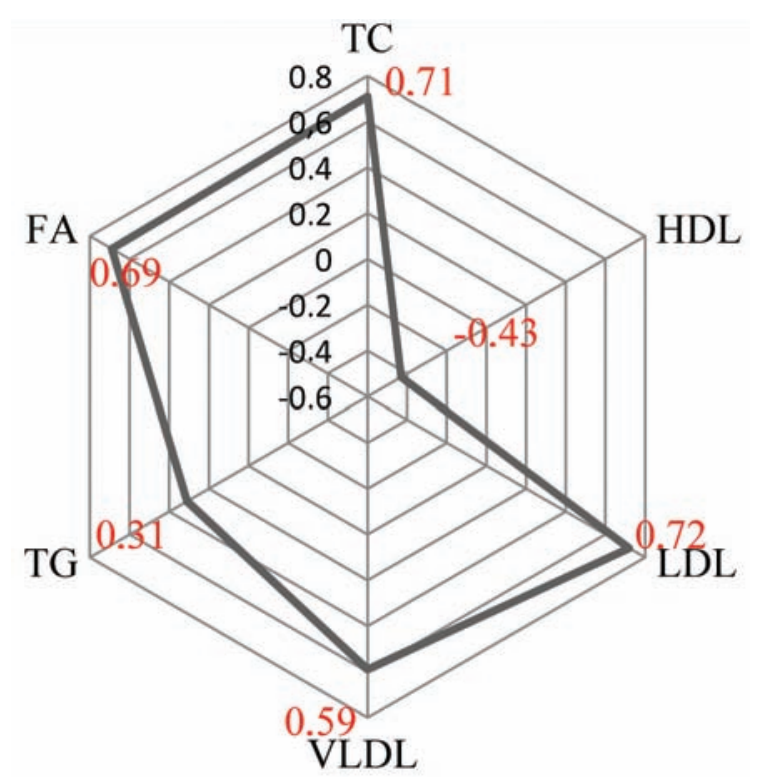

Fig. 1. Graphic representation of power correlation between plasma homocysteine and lipid spectrum of the blood in patients with acute ischemic stroke 


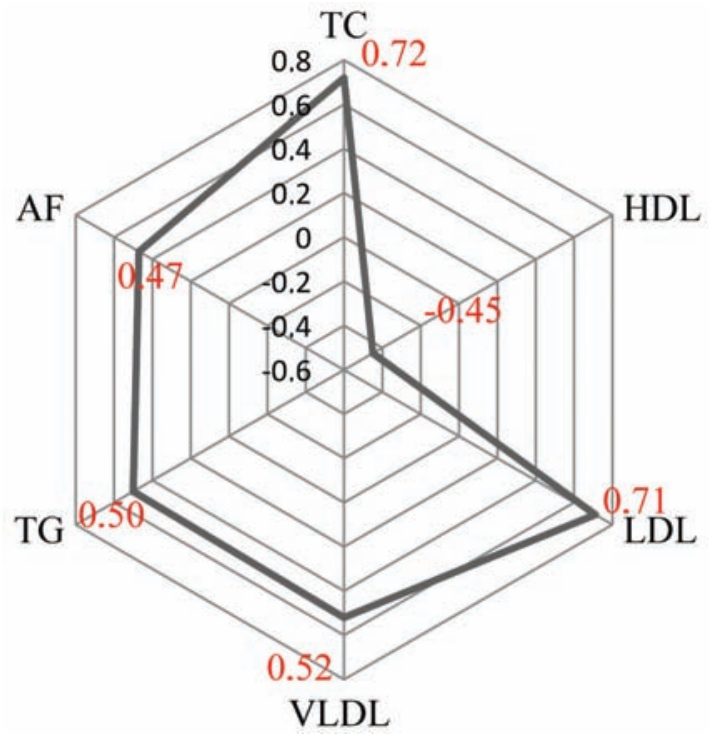

Fig. 2. Graphic representation of power correlation between vascular endothelial growth factor level and lipid spectrum of the blood in patients with acute ischemic stroke

which have a toxic influence on the vascular wall endothelial cells, so the body reacts to this by a compensatory increase in the production of VEGF. Thus, in patients with AIS the increase in HC and VEGF in the blood can act as markers destruction of vascular endothelium, but they have a different genesis and oppositely acting on the vascular wall.

\section{ДЕЯКІ БІОХІМІЧНІ ЗМІНИ У ПАЦІЕНТІВ ІЗ ГОСТРИМ ІШЕМІЧНИМ ІНСУЛЬТОМ}

\section{О. Я. Михалойко, І. Я. Михалойко}

$$
\begin{gathered}
\text { Івано-Франківський національний } \\
\text { медичний університет, Україна; } \\
\text { e-mail: myhalojko@i.ua }
\end{gathered}
$$

Метою роботи було визначити концентраційні зміни васкулоендотеліального фактора росту (ВЕРФ), гомоцистеїну (ГЦ) та показників ліпідограми у пацієнтів із гострим ішемічним інсультом (ГІІ), встановити наявність взаємозв'язку між ними. Проведено клініко-неврологічне обстеження пацієнтів (56-75 р.) 3 ГІІ. Діагноз верифікували за даними спіральної комп'ютерної та магнітнорезонансної томографії, контрольна група пацієнти $(59,35 \pm 1,8$ років) без ознак гострих порушень мозкового кровообігу та важкої соматичної патології. Оцінку неврологічного дефіциту проводили за госпіталізації пацієнтів та в процесі лікування за шкалою NIHSS. Всім тематичним хворим на 1-2-й день після виникнення інсульту методом імуноензимного аналізу було визначено концентрації ГЦ та ВЕФР у крові. Дослідження ліпідного спектра крові проводили ензиматичним колориметричним методом. Під час дослідження виявлено, що збільшення концентрації ГЦ асоціюється iз проявами гіперліпідеміі, причому ступінь проявлення гіпергомоцистеїнемії превалює над характером змін складових ліпідного профілю. За ГІІ відмічено вірогідне підвищення концентрації васкулоендотеліального фактора росту в крові, що свідчить про наявність судинної катастрофи та активацію процесів ангіогенезу. Вираженість ураження судинного ендотелію асоціюється 3 підвищенням концентрації васкулоендотеліального фактора росту, що найбільш показово виявляється у хворих із важким ГІІ.

К л ю чов в с с ов а: гострий ішемічний інсульт, васкулоендотеліальний фактор росту, гомоцистеїн, ліпідний спектр крові.

\section{НЕКОТОРЫЕ БИОХИМИЧЕСКИЕ ИЗМЕНЕНИЯ У ПАЦИЕНТОВ С ОСТРЫМ ИШЕМИЧЕСКИМ ИНСУЛЬТОМ}

\section{О. Я. Михалойко, И. Я. Михалойко}

Ивано-Франковский национальный медицинский университет, Украина; e-mail: myhalojko@i.ua

Целью работы было определить концентрационные изменения васкулоэндотелиального фактора роста (ВЭРФ), гомоцистеина (ГЦ) и показателей липидограммы у пациентов с острым ишемическим инсультом (ОИИ), установить наличие взаимосвязи между ними. При проведении клинико-неврологического обследования пациентов (56-75 лет) с ОИИ диагноз верифицировали по данным спиральной компьютерной и магнитно-резонансной томографии; контрольная группа - пациенты $(59,35 \pm 1,8$ лет) без признаков острых нарушений мозгового кровообращения и тяжелой соматической патологии. Оценку неврологического дефицита проводили при госпитализации пациентов и в процессе лечения по шкале NIHSS. Всем тематическим 
больным в 1-2-й день после возникновения инсульта методом иммуноэнзимного анализа были определены концентрации ГЦ и ВЕФР в крови. Исследование липидного спектра крови проводили энзиматическим колориметрическим методом. В результате исследования установлено, что увеличение концентрации ГЦ ассоциируется с проявлениями гиперлипидемии, причём степень выраженности гипергомоцистеинемии превалирует над характером изменений составляющих липидного профиля. При ОИИ отмечается достоверное повышение концентрации васкулоэндотелиального фактора роста в крови, что свидетельствует о наличии сосудистой катастрофы и активации процессов ангиогенеза. Выраженность поражения сосудистого эндотелия ассоциируется с повышением концентрации васкулоэндотелиального фактора роста, что наиболее показательно проявляется у больных с тяжелым ОИИ.

Ключевы е слова: острый ишемический инсульт, васкулоэндотелиальный фактор роста, гомоцистеин, липидный спектр крови.

\section{References}

1. Ciaccio M, Bivona G, Bellia C. Therapeutical approach to plasma homocysteine and cardiovascular risk reduction. Ther Clin Risk Manag. 2008; 4(1): 219-224.

2. Williams KT, Schalinske KL. Homocysteine metabolism and its relation to health and disease. Biofactors. 2010; 36(1): 19-24.

3. Dietrich-Muszalska A, Malinowska J, Olas B, Głowacki R, Bald E, Wachowicz B, RabeJabłońska J. The oxidative stress may be induced by the elevated homocysteine in schizophrenic patients. Neurochem Res. 2012; 37(5): 1057-1062.

4. Schaffer A, Verdoia M, Cassetti E, Marino P, Suryapranata H, De Luca G. Relationship between homocysteine and coronary artery disease. Results from a large prospective cohort study. Thromb Res. 2014; 134(2): 288-293.

5. Bostom AG, Selhub J. Homocysteine and arteriosclerosis: subclinical and clinical disease associations. Circulation. 1999; 99(18): 23612363.

6. Liu H, Yang M, Li GM, Qiu Y, Zheng J, Du X, Wang JL, Liu RW. The MTHFR C677T polymorphism contributes to an increased risk for vascular dementia: a meta-analysis. $J$ Neurol Sci. 2010; 294(1-2): 74-80.
7. Baños-González MA, Anglés-Cano E, CardosoSaldaña G, Peña-Duque MA, Martínez-Ríos MA, Valente-Acosta B, González-Pacheco H, de la Peña-Díaz A. Lipoprotein(a) and homocysteine potentiate the risk of coronary artery disease in male subjects. Circ J. 2012; 76(8): 1953-1957.

8. Blacher J, Benetos A, Kirzin J, Malmejac A, Guize L, Safar M. Relation of plasma homocysteine to cerebrovascular mortality in a French population. Am J Cardiol. 2002; 90(6): 591-595.

9. Ford AH, Flicker L, Alfonso H, Hankey GJ, Norman PE, van Bockxmeer FM, Almeida OP. Plasma homocysteine and MTHFRC677T polymorphism as risk factors for incident dementia. J Neurol Neurosurg Psychiatry. 2012; 83(1): 70-75.

10. Kumakura H, Fujita K, Kanai H, Araki Y, Hojo Y, Kasama S, Iwasaki T, Ichikawa S, Nakashima K, Minami K. High-sensitivity C-reactive Protein, Lipoprotein(a) and Homocysteine are Risk Factors for Coronary Artery Disease in Japanese Patients with Peripheral Arterial Disease. J Atheroscler Thromb. 2015; 22(4): 344-354.

11. Chi OZ, Hunter C, Liu X, Weiss HR. Effects of VEGF and nitric oxide synthase inhibition on blood-brain barrier disruption in the ischemic and non-ischemic cerebral cortex. Neurol Res. 2005; 27(8): 864-868.

12. Hansen TM, Moss AJ, Brindle NP. Vascular endothelial growth factor and angiopoietins in neurovascular regeneration and protection following stroke. Curr Neurovasc Res. 2008; 5(4): 236-245.

13. Voelkel NF, Vandivier RW, Tuder RM. Vascular endothelial growth factor in the lung. $A m J$ Physiol Lung Cell Mol Physiol. 2006; 290(2): L209-L221.

14. Narasimhan P, Liu J, Song YS. VEGF stimulates the ERK 1/2 signaling pathway and apoptosis in cerebral endothelial cells after ischemic conditions. Stroke. 2009; 40(4): 1467-1473.

15. Ma Y, Qu Y, Fei Z. Vascular endothelial growth factor in cerebral ischemia. J Neurosci Res. 2011; 89(7): 969-978.

Received 12.03.2017 